\title{
Aspectos de la cultura política del carlismo en el siglo XX
}

\author{
Josep Miralles Climent \\ UNED
}

\section{Carlist political culture in the $20^{\text {th }}$ Century: some aspects}

\begin{abstract}
RESUMEN
A través de unas cuantas pinceladas de hechos $y$ acontecimientos que se han dado en el movimiento carlista durante el siglo $x x$, he intentado plasmar el desarrollo o evolución de su cultura política. He partido de la base de que el carlismo es un movimiento más complejo de analizar de lo que a simple vista parece; que su evolución no ha sido lineal, y que no se puede hablar de uno, sino de varios carlismos. En este trabajo me he centrado en los acontecimientos que ha venido reivindicando el sector más progresista del mismo, y que de alguna manera son la justificación de su evolución hacia la izquierda, pero sin desdeñar otros aspectos que estarian más próximos al sector tradicionalista. He focalizado la evolución político-cultural del carlismo en los siguientes aspectos: la religiosidad; la sociabilidad en los Círculos

Culturales; la defensa de las culturas autóctonas periféricas; la cultura obrera y sindical; la cultura juvenil y estudiantil; la

cultura de la violencia; fiestas, ritos y conmemoraciones carlistas; y la evolución cultural e ideológica, incluyendo el papel

de las mujeres. Todo ello se ve atravesado por un importante elemento de su historia como ha sido la defensa de la
\end{abstract}

\section{ABSTRACT}

Across a few facts and events that have been given in the carlist movement during the 20th century, I have tried to shape the development or evolution of its political culture. I have started from the base that carlism is a more complex movement to analize that at first sight seems, that its evolution has not been linear, and one cannot speak about just one carlism but several ones. In this work I have centred on the events that have been reivindicated by carlism more progressive sector, and that somehow, are the justification of its evolution towards the left side of politics, but without disdaining other aspects closer to the traditionalist sector. I focused the carlism political and cultural evolution in the following aspects: the religiousness; sociableness in the Cultural Circles; autochthonous peripheral cultures defense; the labour and syndical culture; youthful ans student culture; the culture of the violence; holidays, rites and carlist commemorations; and cultural and ideological evolution, including the role of women. All of these aspects are affected by an important element of their history as it has been the defense of the legitimacy, that is, its union with a dinasty that has been proscribed since carlism birth. Such 
legitimidad, es decir, su adhesión a una dinastía que ha estado proscrita desde el nacimiento del carlismo. Una marginación que ha alcanzado también al propio movimiento que, pareciendo nadar siempre a contracorriente, ha permanecido en posiciones alejadas no sólo del poder, sino de la cultura dominante en cada momento de su historia. a marginalization reached also to the movement itself that, seeming to swim always cross current, has remained along its history, far away not only from the power but from the dominant culture every time.

KEYWORDS:

Political culture; Carlism; Progressive sector; Traditionalist sector; Legitimacy.

PALABRAS CLAVE:

Cultura política; Carlismo; Sector progresista; Sector tradicionalista;

Legitimidad.

\section{INTRODUCCIÓN}

El carlismo es un fenómeno histórico hispánico que ha dado mucha bibliografía de diversa índole, sobre todo histórica, pero muy centrada en sus aspectos militares, asociados a una confrontación ideológica progreso/reacción o revolución/tradición. Otros aspectos de su cultura política, o si se quiere subcultura, a lo largo de su larga historia, han quedado relegados a un segundo o tercer plano, y no digamos ya los aspectos estrictamente culturales que también ha generado. Aqui trataré de hacer un repaso a algunos aspectos relacionados con la cultura política; porque lo social, lo ideológico, lo político y hasta lo militar forma parte de la cultura, en el amplio sentido de la palabra; cultura en minúsculas, eso sí, no la alta cultura que, aunque poca, también la ha propiciado, sino la que nace del sentir colectivo de una comunidad de gentes que, dicho sea de paso, no ha sido tan monolítica como a veces se piensa. Efectivamente, no se puede hablar de carlismo, sino de carlismos. Ante la dificultad de afrontar un estudio sobre sus diversas "culturas", me centraré en las tendencias más en línea con la modernidad, pero sin despegarme de ese fondo de carácter tradicional que de alguna manera también se ha mantenido en las actitudes de lo que podríamos llamar "izquierda" carlista o carlismo «progresista».

En primer lugar es necesario constatar que el movimiento carlista, en líneas generales, parece no haber encajado demasiado bien en la mayoría de tendencias historiográficas que han ido dominando a lo largo de su ya dilatada historia. El carlismo se ha considerado como un fenómeno marginal, cuyo conocimiento no merecía demasiado interés, bien porque se consideraba simple y llanamente una cultura reaccionaria, contraria al progreso, o bien porque se hallaba al margen del sistema dominante.

Por otra parte, conviene diferenciar entre las culturas intrínsecas más o menos populares del carlismo, y la alta cultura o arte que, como ya he dicho, ha ido generando, al inspirar a escritores, pintores y grabadores principalmente, como pue- 
den ser, Valle-Inclán, Pérez Galdós, Baroja, Unamuno, Marià Vayreda o Sánchez-Ostiz en literatura y Cusachs, Fortuny, Joaquim Vayreda, Zuloaga o Sáenz de Tejada en pintura, a parte de las numerosas obras menores, muchas de las cuales de autores desconocidos. Hasta el mismo cine ha llegado a producir recientemente alguna interesante obra dedicada total o parcialmente al carlismo, como Vacas y La pelota vasca, de Julio Médem, o Crónica de la guerra carlista y Santa Cruz, el cura guerrillero, de José María Tuduri'.

Conviene tener en cuenta también que, aunque el carlismo fue aparentemente un movimiento legitimista, su adhesión contenía, además, elementos diversos de tipo emocional y mítico, muy acorde con un tipo de rebeldía primitiva que se guiaba más por los impulsos que por el raciocinio. Algo, por otra parte, más propio del tipo de cultura popular que de la cultura aristocrática y burguesa que inspiraría a su eterno enemigo: el liberalismo. Sin embargo, aunque en sus orígenes el movimiento carlista fuera espoleado por esa especie de reacción instintiva contra las consecuencias sociales - nefastas en la España decimonónica- así como contra la nueva cultura, fruto ambas de la Revolución Industrial y de la Revolución Francesa, a lo largo del tiempo y manteniendo como hilo conductor el legitimismo, se fue adaptando a las nuevas formas culturales, a la vez que reelaboraba unos "principios racionales", para ir dando respuesta a nuevos problemas sociales. Pero, la mayor parte del tiempo, sin perder de vista unos principios culturales de tipo tradicionalista.

En cualquier caso, esos "principios racionales" reinterpretados a la luz de la cultura de cada época, casi siempre estuvieron, o bien enfrentados a esa cultura oficial o dominante, o bien fuera de los límites de la misma; durante el siglo xIX frente al liberalismo; en el siglo xx frente a la democracia. Sin embargo, el carlismo no era el único movimiento que se oponía al liberalismo y a la democracia. También los grupos izquierdistas, más o menos revolucionarios, y las diversas formas de fascismo, combatieron la cultura liberal y democrática, cada cual con sus argumentos. Siendo como fue el carlismo un movimiento con bastante apoyo popular -al menos en importantes zonas de España- ¿por qué la historiografía y la cultura oficial le han prestado menos atención que al anarquismo, a la Falange o a los diversos grupos marxistas? Las causas habría que buscarlas en varios niveles: en primer lugar, porque se le ha considerado lisa y llanamente un movimiento reaccionario, antihistórico, anclado en un pasado cuasimedieval, al que no merecía prestarle la más mínima atención. En segundo lugar, porque consecuente con sus orígenes diversos su larga historia está plagada de escisiones y distintas interpretaciones, tanto desde el punto de vista político-organizativas como ideológicoculturales, formando una amalgama difícil de entender. $Y$ en tercer lugar, porque en su conjunto siempre se ha hallado muy lejos del poder de turno correspondiente.

' En relación a La pelota vasca, véase el disco 1, de la edición especial en 3 CD's. Para otras películas más antiguas, puede verse TuduRI, José Maria, "Las Guerras Carlistas en el cine" en el excelente catálogo Las Guerras Carlistas, Ministerio de Cultura, Madrid, 2004, pp. 114-124. Parece que existe un interesante proyecto universitario entre San Pablo-CEU y la UNED para realizar un documental sobre la Primera Guerra carlista: ver El Federal, julio, 2004, p. 7. 
Al referirme, en el punto anterior, al secular enfrentamiento del carlismo con la cultura dominante, tal vez no esté de más establecer un paralelismo con fenómenos del mundo actual que pueden ayudar a comprender la actitud de un cierto carlismo que en su momento también reaccionó contra las consecuencias de la implantación del capitalismo en España, y que pueda contarse, como dice el profesor Aróstegui, «entre los movimientos de protesta popular propio de los orígenes del capitalismo" ${ }^{2}$. Conviene, pues, recordar que la cultura dominante hoy, en el mundo occidental donde vivimos, es más o menos una cultura capitalista, liberal, de mercado, democrática, y laica; unos principios que, entre la elite cultural, casi nadie cuestiona porque aparecen como el mal menor para afrontar la conflictividad y la complejidad del mundo moderno. Sin embargo hoy -como ayer-puede ser que "otro mundo sea posible», como se dice desde los movimientos alternativos. Unos movimientos muchas veces tildados de reaccionarios -como lo fue el carlismo- porque cuestionan las que consideran como falsedades de unos principios que, en la era de la globalización, sólo sirven para justificar, dicen, el expolio del tercer mundo y la explotación capitalista a nivel mundial, donde empeoran las condiciones de vida de sus gentes, así como la falta de libertad y democracia en cuestiones que vayan más allá del simple voto electoral, por no hablar de la falacia de la libertad del mercado. Tal vez sea conveniente que nos preguntemos: ¿es realmente el mundo moderno el mejor posible para el conjunto de la humanidad? Lo dicho viene a cuento para inducir al lector a cuestionarse algo que a simple vista parece obvio: el indiscutible progreso del ser humano y de su cultura ${ }^{3}$. Con ello pretendo no desdeñar un cierto relativismo cultural. Eso puede ayudar, como dije antes, a comprender el fenómeno cultural de al menos determinados aspectos del movimiento carlista.

En cualquier caso, justo es reconocer que el carlismo y el tradicionalismo carlista han participado en el devenir de la cultura política de España con un importante acervo del que ha sido artífice. Aunque en su mayor parte ha ido asumiendo eso que se llama progreso con un tiempo de desfase, en otras cuestiones se ha anticipado a movimientos tenidos por progresistas. En las siguientes páginas voy a intentar sacar a la luz algunos de los aspectos de la cultura política de carlismo, aunque referidos especialmente al siglo $\mathrm{XX}$, de forma esquemática y por supuesto no de forma totalizante. Incidiré más en aquellos temas de su cultura política que

\footnotetext{
2 ARóstegul, Julio, "Carcas' y 'Guiris'. La génesis del carlismo" en Historia 16, año II, n. 13 , mayo 1977, p. 63.

3 Hay un buen número de autores y publicaciones, críticas con el sistema, que se plantean de forma muy seria todas estas cuestiones. Me limitaré a mencionar unos cuantos ejemplos que afrontan el tema desde muy distinta ideología o enfoque: el lingüista CHOMSKY, Noam, Obra esencial Crítica, Barcelona, 2002; la periodista RoмA, Pepa, Jaque a la globalización, Círculo de Lectores, Barcelona, 2001; el historiador NoBLE, David F. Una visión diferente del progreso. En defensa del luddismo Alikornio, Barcelona, 2000; el economista AmIN, Samir, El capitalismo en la era de la globalización, Paidós, Barcelona, 1998; el sociólogo ZIEGLER, Jean, La victoria de los vencidos Ediciones B, Barcelona, 1988. Otros críticos han tratado el tema desde la óptica cristiana como González FaUs, o desde el Islam, como Garaudy, Roger. Hay muchos más pensadores «malditos" para el sistema como: Eduardo Galeano, Leonardo Boff. Ignacio RAMONET, Susan GEORGE, y un largo etcétera.
} 
contribuyan a desmitificar esa visión tópica de un carlismo feroz, integrista o fundamentalista, anclado en el pasado, que seguramente es la imagen vulgar más extendida.

\section{LA INFLUENCIA DE LA RELIGIÓN}

Es sabido que históricamente la defensa de la cultura religiosa católica, de su Iglesia y de una determinada idea de Dios, ha jugado un papel de gran importancia en el carlismo. Pero, aunque es difícil de evaluar, me atrevería a decir que esa defensa se hizo más patente de una forma explícita durante la época central de la historia del carlismo, es decir, a partir de la revolución de 1868 y hasta dos décadas después de terminada la guerra civil española, aunque con altibajos. Ello fue debido, según algunos autores, a la influencia que ejercieron los neocarlistas y los integristas católicos que engrosaron las filas del carlismo como reacción ante la Gloriosa. Porque en sus orígenes se daba más bien lo que Terrades denomina cultura de la religiosidad, no de cuestiones eclesiásticas y teológicas ${ }^{4}$; y a partir de finales de los años cincuenta del siglo xx, la identificación con el hecho religioso ha estado más unida a una determinada interpretación de la cultura religiosa, que a la institución eclesial propiamente dicha. Es por eso que durante la primera mitad del siglo xx se dio más el fenómeno de defensa de la Iglesia católica, en contraste con la segunda parte del siglo, en que predominó la influencia cultural del cristianismo católico.

A pesar de que don Jaime, el abanderado carlista del momento, aceptó con prudencia el advenimiento de la República, los ataques del mes de mayo a edificios religiosos convencieron ya a los pocos carlistas incrédulos de que se vivía en la antesala del comunismo y la anarquía. Por eso, el culmen de la defensa de la Iglesia se dio durante esa época, iniciándose a partir de mayo de 1931. Esa defensa y la lucha contra el anticlericalismo resultarían los principales elementos movilizadores en los inicios de la Segunda República que desde sus primeros momentos ya expulsó a prelados; se produjeron incendios de iglesias y conventos; se secularizaron los cementerios; se disolvió la Compañía de Jesús; y se hicieron desaparecer los crucifijos de las escuelas 6 : Incluso en esta época, y en contraste con la conocida frase del pretendiente Carlos VII de que no daría ni un paso más adelante ni uno más atrás del que diera la Iglesia católica, el carlismo tuvo más empeño en la defensa de la Iglesia, que la propia jerarquía católica.

Durante la guerra y en los primeros lustros, tras su finalización, el factor religioso católico continuó impregnando de forma importante los escasos aconteci-

\footnotetext{
4 Tefrades, Ignasi, "Una aproximació al món cultural carli" en IV Seminari sobre el carlisme (Solsona, 15-16 de marzo de 1996) Columna, Barcelona, 1997, p. 10.

${ }^{5}$ Canal, Jordi, El carlismo, Alianza Editorial, Madrid, 2000, p. 288.

${ }^{6}$ AlcalÁ, César, D. Mauricio de Sivatte. Una biografía politica (1901-1980), Scire, Barcelona, 2001, p. 17.
} 
mientos protagonizados por el carlismo, a pesar de su divergencia respecto a la jerarquía católica en cuanto a la aceptación de la dictadura franquista, ya que mientras los sectores mayoritarios del carlismo eran desplazados e incluso perseguidos, la Iglesia española cerró filas en torno al régimen político de Franco. Un carlista, el padre Artur Juncosa, estudiante en la inmediata posguerra, habla del fuerte catolicismo que tenian y de que muchos carlistas pertenecian a las Congregaciones Marianas y a la Acción Católica, pero dice también que fue aquí, en la Acción Católica, donde por primera vez oyó hablar de la doctrina social de la Iglesia que él identificó como contraria al capitalismo'.

Progresivamente, $y$ hasta el final del siglo $x x$, el factor religioso fue perdiendo importancia en beneficio de aspectos políticos y sociales, como se irá viendo a lo largo de este trabajo. En cualquier caso, todos los actos carlistas durante el franquismo se presentaban y por supuesto se solicitaban como actos religiosos $\multimap$ patrióticos- para honrar la memoria de los muertos carlistas (identificados como mártires) habidos a lo largo de su historia. Pero, al margen de esto, si en los dos primeros tercios del siglo la religiosidad carlista, en línea con la Iglesia española, tuvo un carácter integrista, a partir del concilio Vaticano II esa religiosidad se fue trocando en progresista hasta llegar a identificarse con la que mantenian los sectores más avanzados de la Iglesia española en particular, y con los de la «teología de la liberación” desde un punto de vista más amplio ${ }^{8}$. En este sentido se enmarcan la carta y el informe dirigidos en 1974 por el máximo dirigente del Partido Carlista, don Javier de Borbón Parma, al presidente de la Conferencia Episcopal Española, donde, después de aclarar que «aunque el Carlismo esté compuesto casi en su totalidad por católicos, no es confesional», se denuncia «la posición ambigua de la Iglesia Jerárquica en España porque la considera un testimonio de colaboración con el sistema»9.

\section{LOS CÍRCULOS CARLISTAS, ESPACIOS DE SOCIABILIDAD}

A partir de 1897 y como consecuencia del contenido programático del Acta de Loredán el carlismo emprende una revisión fundamentalmente organizativa, en un intento de modernización. Los círculos carlistas estaban ya extendidos por toda la geografía hispánica con gran actividad socio cultural. Sin embargo, en noviembre de 1900, tras el fracaso de un conato insurreccional, el Gobierno decidió clausurar todos los organismos dependientes del carlismo, y con ella los círculos.

7 JUNCOSA, Artur, «L'organització del moviment universitari carlí del anys quaranta» en VI Seminari d'Historia del carlisme (Solsona, 24-25 de març de 2000), Fundació Francesc Ribalta, Solsona, 2002, p. 209.

8 Es conocida la militancia carlista del sacerdote navarro Rodolfo Izal, detenido en Chiapas y expulsado, como persona no grata, por el gobierno mexicano, acusado de supuestas actividades a favor del movimiento zapatista. Ver Boletín del Partido Carlista de Euskalherria, n. ${ }^{\circ} 45$, febrero 1994, p. 11, y entrevista en el n. ${ }^{\circ} 51$, tercer trimestre 1995, pp. 7-9. También en $I M$, junio 1995, p. 3.

9 Clemente, Josep Carles, Historia general del Carlismo, Ed. F. Mesa-Servigrafint, S.A. Madrid, 1992, p. 924. 
Unos años más tarde muchos círculos carlistas iban reabriendo sus puertas y otros se crearon ex novo. Algunas de las novedades de estos círculos de principios de siglo fueron las actividades deportivas como los clubes de fútbol, ciclismo, pelota, que constituía un poderoso elemento de socialización y la potenciación de las juventudes, proliferando los gimnasios y las prácticas de tiro, pero también, más adelante, veladas literario-musicales, además de bailes, juegos, teatro, grupos de danzas folclóricas, etc. Algunos disponian de sección obrera y hasta de bolsa de trabajo. Asimismo en los círculos se combinó la caridad junto al mutualismo y la escolarización. La sociabilidad era sobre todo masculina con progresiva penetración de las mujeres que con el tiempo tendrían su propia organización: las «Margaritas". En líneas generales los círculos intentaron remarcar su carácter popular ${ }^{10}$. El centro carlista conocido como El Paller y el semanario Joventut que dirigía el carlista catalán Tomàs Caylà fueron en 1930 importantes artífices de la renaixença castellera en Valls, donde uno de los dos grupos, la Colla Vella, que era la de los labradores, también era conocida por la Colla dels carlins ${ }^{11}$.

Algunos conflictos por recuperar tierras comunales en Navarra se gestaron en círculos carlistas, varios de los cuales se reconvirtieron en centros obreros de izquierda al acercarse la Segunda República. El círculo de Allo se convirtió en ateneo libertario ${ }^{12}$. Un fenómeno similar se había dado ya a finales del siglo xIx en el Baix Penedès, donde los carlistas evolucionaron hacia el republicanismo ${ }^{13}$.

Desde los círculos se dio el salto a la plaza, a la conquista del espacio público con organización de mítines, banquetes multitudinarios y actos públicos de masas que se prolongarían hasta bien entrados los años 60 , cuando el carlismo se vio abocado a la semiclandestinidad a raíz de la expulsión de los Borbón Parma (familia real carlista). Una situación que no era nueva, porque a lo largo del siglo ya habían pasado por otras etapas de censuras, detenciones, multas y prohibiciones durante la dictadura de Primo de Rivera primero, así como la propia dictadura franquista en los años que siguieron a la guerra civil. Efectivamente, el régimen totalitario de Franco dio un golpe importante al funcionamiento de estos círculos al imponer la unificación y un partido único que no permitía ninguna formación política diferenciada a FET de las JONS. Por eso el régimen de Franco negó toda posibilidad de resurrección de la extensa red de círculos que existía antes de la guerra. Sin embargo, en algunos lugares se crearon entidades legales que encubrían la actividad carlista. Así, en Vila-real se constituyó en 1940 una sociedad recreativa denominada Peña España, que aún hoy sigue siendo sede del Partit Carlista de

10 Canal, Jodi, El carlismo, ob. cit. pp. 256-257 y 296.

1 GuinOVART, Joan, Tomàs Caylà, un home de la terra, Cossetània, Valls, 1997, pp. 115-131. (Los castellers, son cuadrillas de hombres que forman torres humanas, típicas de Cataluña).

12 Esparza, José Mari, ¡Abajo las quintas! La oposición histórica de Navarra al Ejército español, Txalaparta, Tafalla, 1994, p. 263.

${ }_{13}$ MILLÁN, Jesús, “Contrarevolució i mobilització a l'Espanya contemporània» L'Avenç n. ${ }^{\circ} 154$, diciembre 1991, p. 17. 
País Valencià ${ }^{14}$, y en Barcelona, por ejemplo, nació el Círculo Familiar Montserrat que, inaugurado oficialmente en 1951, tuvo una gran vida y actividad cultural de conferencias, teatro, conciertos, juegos y bar ${ }^{15}$.

A partir de 1959, en un ambiente de tolerancia hacia los carlistas, comenzaron a abrirse por toda España una red de círculos culturales, la mayoría de los cuales se denominaba "Vázquez de Mella", que en 1962 ya contaba con 59 delegaciones $^{16}$. Estos círculos, en donde se desenvolvían diversas organizaciones carlistas y tradicionalistas (“Margaritas", excombatientes, requeté, estudiantes y obreros), sirvieron en muchos casos como plataforma para combatir la política oficial del régimen. Como se documenta en el caso del de Zaragoza, donde la policía detuvo y procesó a ocho carlistas por confección y distribución de propaganda clandestina, siendo el principal detenido el jefe de cultura, Manuel Zabala Sevilla, junto a otros responsables de organizaciones femeninas, obreras y de estudiantes ${ }^{17}$.

\section{DEFENSA DE LAS CULTURAS AUTÓCTONAS}

Uno de los principales estudiosos del nacionalismo lo ha definido como una doctrina universal inventada en Europa a principios del siglo $x \mid x^{18}$. Hasta 1848 el nacionalismo estuvo unido al liberalismo y a la democracia, pero desde entonces se fue impregnando de los valores de la tradición. Cuando el nacionalismo español comenzó a consolidarse en España tuvo que lidiar con las idiosincrasias de los diversos pueblos que la constituían, en especial los de la antigua Corona de Aragón y los de Euskalherria, teniéndose que enfrentar a los viejos fueros, asociados a esos pueblos, que los carlistas optaron por defender.

Pero no todos los carlistas eran foralistas, porque, aunque fue ya durante el siglo Xx, hubo también en el carlismo una intelectualidad proclive al nacionalismo español. El paradigma fue Víctor Pradera, un discípulo de Vázquez de Mella, que estaba obsesivamente preocupado por la unidad española y por el auge de los nacionalismos periféricos en el cual los carlistas participaban. Pradera sobresalió en sus propuestas por un antiautonomismo al que contraponía un tradicionalismo español donde los fueros eran un título de amor a España ${ }^{19}$. Se marchó con Mella cuando éste se escindió del partido carlista y regresó más tarde, como también lo

\footnotetext{
14 V:LAR, Carles, El círculo carlista de Vila-real, un ejemplo de autogestión, Cuadernos de Historia del carlismo, n. ${ }^{\circ} 22$, marzo de 2002.

${ }^{15}$ Fel.u, Carles, "El carlisme català sota el franquisme". en VI Seminari d'Historia del carlisme (Solsona, 24-25 de març de 2000) Fundació Francesc Ribalta, Solsona, 2002, pp. 171-173.

${ }^{16}$ CASPIStegul, Francisco Javier, El naufragio de las ortodoxias. El carlismo, 1962-1977, Eunsa, Pamplona, 1997, p. 117; CUBERo, Joaquín, «El Partido Carlista. Oposición al Estado franquista y evolución ideológica (1968-1975)" en: La oposición al régimen de Franco, Madrid, 19 a 22 de octubre de 1988, Tomo I, vol. 1, Madrid, UNED, 1990, p. 400.

17 CASPISTEgUI, Francisco Javier, El naufragio de las ortodoxias, cit., p. 109.

18 Kedourie, Elie, Nacionalismo, Centro de Estudios Constitucionales, Madrid, 1985. Citado por Isidro Sepúlveda en Historia del Nacionalismo (en internet, sin paginar).

19 CANAL, Jordi, El carlismo, cit., p. 269.
} 
hicieron los integristas, ya con el miedo a la República. Todo ello estuvo favorecido también por la mentalidad integrista de don Alfonso Carlos, cabeza del carlismo de la época, tras la muerte de su antecesor, en octubre de 1931, de aquel socialista sincero que fue don Jaime ${ }^{20}$. Seguramente la presidencia de Pradera en el Consejo de Cultura Tradicionalista creado en 1934 debió de favorecer el incremento del nacionalismo español del carlismo en esos tiempos, así como el entusiasmo de su participación en el Bloque Nacional de Calvo Sotelo ${ }^{21}$. No es casualidad que, tras su muerte en 1939, Franco prologara su obra.

Al margen de este paréntesis, la conciencia profunda del movimiento carlista parece que iba por otros derroteros. Así, en Euskalherria (País Vasco y Navarra) la defensa de las constituciones forales fue una importante razón de la inicial rebeldia carlista que tuvo su continuidad en el tiempo. En otros pueblos peninsulares, esta reivindicación se introdujo un poco más tarde, pero a principios del siglo xx casi todo el carlismo ya había asumido esa defensa, que ahora iba evolucionando hacia un cierto protonacionalismo periférico, especialmente en Euskalherria, Países Catalanes y Galicia, como reacción al absorbente centralismo estatal. En este sentido, la conciencia foralista del tradicionalismo carlista acercó a éste hacia los movimientos nacionalistas de estos pueblos. En Galicia, «el carlismo, de justa y amplia base regionalista, estuvo muy ligado a los ideales autonomistas: a partir, sobre todo, del ilustre y malogrado Alfredo Brañas, muerto en juventud "22.

En Cataluña, a principios de siglo nace el movimiento solidario en el contexto del Noucentisme. La participación carlista en Solidaritat Catalana significa, entre otras cosas, la inmersión de este grupo en la dinámica nacionalizadora ${ }^{23}$. "Desde entonces estableció alianzas preferentes con la Lliga y su portavoz, El Correo Catalán, a partir de 1903, tuvo una orientación catalanista»24. En 1903 el carlista Marià Vayreda publica La punyalada, una de las grandes novelas del final del realismo catalán. En el nacimiento del catalanismo juega un papel importantísimo Prat de la Riba, fundador del Institut d'Estudis Catalans, y hombre claramente de estirpe carlista ${ }^{25}$.

Igualmente en el Pais Valenciano el carlismo promovió en 1907 otro proyecto parecido al de Solidaritat Catalana junto a los republicanos sorianistas, pero fue una iniciativa que, combatida por el blasquismo, naufragó en sus inicios ${ }^{26}$. Isabel

20 Melgar, Francisco, Don Jaime, el Príncipe caballero, Espasa-Calpe, Madrid, 1932, pp. $173-174$. (Citado por Clemente, Josep Carles, en: Historia General del Carlismo, ob. cit. p. 356).

21 CANAL, Jordi, El carlismo, ob. cit. p. 315.

22 CAstroviejo José María, «El carlismo gallego en mi recuerdo» Destino, 30-4-1966, cit. en EI Federal $n .^{\circ} 5$, abril, 2000 , p. 13. Para esta relación entre el tradicionalismo y el regionalismo gallego ver también Alberca, Manuel y González, Cristóbal: Valle-Inclán. La fiebre del estilo Espasa, Madrid, 2002, p. 51.

23 Canal, Jordi, ob.cit., p. 259.

24 SÁNCHEZ, Josep, El carlisme al territori de l'antiga diòcesi de Tortosa, Arola, Tarragona, 2004, vol. 1, p. 24.

25 Conferencia pronunciada por Jordi Pujol en el Centro Catalán de Madrid el 30 de noviembre de 1981 según reseña de Vicent Catalán en El Federal n. ${ }^{\circ} 14$, julio 2002, p. 14.

26 REIG, Ramir, "Un valencianisme mal educat» en L'avenç n. ${ }^{\circ} 214$, mayo, 1997, p. 20. 
Peñarrubia también ha puesto de manifiesto la canalización foralista en Mallorca de determinadas reivindicaciones populares, junto a otras de tipo más intelectual ${ }^{27}$.

Pero el más importante quehacer en defensa de la cultura autóctona por parte de intelectuales y escritores carlistas se dio en el País Vasco-Navarro, donde a decir del profesor López Antón los carlistas contaron con una larga pléyade de poetas y escritores que había permanecido aislada y olvidada, y que él mismo se encarga de sacar a la luz en un reciente y profundo estudio ${ }^{28}$. El libro hace un repaso, en la primera parte, a la aportación intelectual a la cultura vasca de escritores carlistas de diferentes escuelas y modalidades que van desde los de siglo xIx, ligados al sentimiento foral vasco-navarro anteriores a la impronta aranista, hasta otros que abarcan buena parte del siglo xx. La segunda parte del libro está dedicada a la reconstrucción de la idiosincrasia intelectual y popular. Estas raíces culturales se seguian manteniendo en los años 60 y 70 . Por eso Jon Juaristi dice que "cuando desde ETA comenzamos a colaborar con los Grupos de Acción Carlista (...) hice amistad con algunos jóvenes pistoleros carlomaoistas de la comarca (...) Atendiendo sólo a criterios lingüísticos y etnológicos, puedo afirmar que eran mucho más vascos que yo. Hablaban perfectamente el eusquera; es decir, hablaban sólo en eusquera. Jugaban al frontón endiabladamente bien y no dudo que nos habrian puesto en ridículo, a mí y a todos los etarras urbanícelas, si hubiéramos tratado de competir con ellos bailando la jota o el aurreskus'29.

En 1930 los carlistas catalanes elaboraron un Projecte d'Estatut de Catalunya de tipo confederal ${ }^{30}$, y durante la Segunda República el carlismo participó en la elaboración de anteproyectos de Estatuto de autonomía para el País Vasco y Navarra junto al PNV, y apoyó el de Cataluña en el referéndum de $1931^{31}$. El anteproyecto del de Euskalherria, aprobado por la Magna Asamblea de Municipios Vascos, no fue, sin embargo, ratificado en Madrid, sin duda porque se reservaba «para el Estado Vasco, entre otras facultades, la de regular libremente sus relaciones con la Iglesia», 32 lo cual fue seguramente lo que llevó a decir a Indalecio Prieto que lo que se pretendía era un «Gibraltar vaticanista». Lo que por otra parte no hubiera dejado de responder tanto a las raices espirituales vascas como a su religiosidad, asumida por el carlismo - y también por la mayor parte del nacionalismo vasco- durante esa etapa central de su historia.

${ }_{27}$ PeÑarRUdiA, Isabel, «Permanència i canvi des de la litaratura tradicionalista (1868-1923)» en: $\mathrm{Li}$ teratura, Cultura i Carlisme. III Seminari sobre cartisme (Solsona, 18-19 de març de 1993) Columna, Barcelona, 1995, p. 351.

${ }^{28}$ LÓPEZ, José Javier, Escritores carlistas en la cultura vasca. Pamiella, Pamplona, 2000.

29 JUARISTI, Jon, El Bucle Melancólico. Historias de Nacionalistas Vascos. Espasa, Madrid, 1999, p. 328.

30 "Siempre lo hemos tenido claro", El Federal, n. ${ }^{\circ}$ 14, julio, 2002, p. 13.

${ }^{31}$ CANAL, Jordi, El carlismo, ob. cit. p. 290. Ver también SÁNCHEZ, Josep, El carlisme al territori de l'antiga diòcesi de Tortosa, cit. Vol. 1, p. 24.

32 Clemente, Josep Carles, El carlismo en su prensa (1931-1972), Fundamentos, Madrid, 1999, p. 143. 
Abundando en lo expuesto, para el caso catalán de las tierras del Ebro, el profesor Sánchez Cervelló dice que «...la percepción identitaria que como colectividad tenemos los ciudadanos del Ebro, se debe en gran parte a la herencia del carlismo, especialmente en el aspecto de resistencia al Estado que, posteriormente, a partir de esta experiencia, la CNT y el movimiento libertario impulsarán durante la II República y la Guerra Civilı33. El compromiso carlista en la defensa de las autonomías de los diferentes pueblos de España se verá plasmado en el juramento que hizo don Javier de Borbón Parma, cabeza del carlismo, a los fueros vascos, hecho en Guernica en plena guerra civil y renovado en 1950. Lo mismo hace en Cataluña, en 1951, con los fueros catalanes ${ }^{34}$.

Pero la defensa del catalanismo -como de otras culturas periféricas- no se circunscribió específicamente al terreno político, se dio también en el terreno estrictamente cultural, y no sólo en los Países Catalanes. Asi lo atestigua un curioso documento de noviembre de 1965, difundido nada menos que en Madrid, firmado por los «Estudiantes Carlistas» de la AET, difundido tal vez con motivo de algún recital del cantante valenciano Raimon, que decía entre otras cosas:

«Raimon, no es un fenómeno aislado que haya surgido de manera espontánea. Por el contrario, es el exponente, un exponente de una realidad espiritual a la que pertenecen seis millones de españoles, (Catalanes, Valencianos y Mallorquines) y que tienen un nombre: Cultura Catalana. (Habria que) llevar a efecto una real política de liberación cultural por la que se permitiese a cada español (el problema se extiende al País Vasco y Galicia), elegir la cultura en que (...) deseasen fuesen educados sus hijos. Derecho explícitamente reconocido en el Artículo 2 (...) de los Derechos del Hombre. París 1957. (...) Los universitarios carlistas (...) hacemos esta Declaración en defensa de una cultura española, hoy representada por los nombres de Espriu, Fuster, Cuixart, Casals, Miró,... Raimon, y a la que todos nos sentimos en la obligación de defender y proteger. . ${ }^{35}$

Por otra parte, el reconocimiento de la personalidad propia de La Rioja en diciembre de 1968 servirá de excusa para la expulsión de don Javier y de toda su familia por parte del régimen franquista. La filosofía de estas actitudes queda reflejada en una exposición del líder carlista que dice asi: «Es principio fundamental del ideario carlista el reconocimiento y respeto de la personalidad de las regiones históricas, creaciones vivas y naturales de la nación española, que a pesar de las imposiciones centralistas de los dos últimos siglos, han mantenido su vigencia en el pueblo y en la organización política de la Comunión Tradicionalista» ${ }^{36}$.

${ }^{33}$ SÁnCHEZ, Josep, El carlisme al territori de l'antiga diòcesi de Tortosa, cit. Vol. 1, p. 30.

${ }^{34}$ Clemente, Josep Carles, El Carlismo en la España de Franco. Bases documentales 1936-1977, Fundamentos, Madrid, 1994, pp. 27 y 61.

35 Archivo del autor. Se trata de un folio y medio fotocopiado, procedente del archivo de Amadeu Ciscar de Massanassa.

${ }^{36}$ Clemente, Josep Carles, El Carlismo contra Franco, Flor del Viento Ediciones, Barcelona, 2003, p. 62. El autor recupera con este libro su versión integra original con algunos añadidos, así como su título primitivo, que fueron censurados en su día, y cuyas dos ediciones se agotaron rápidamente, bajo el título de: Historia del Carlismo contemporáneo 1935-1972 Grijalbo, Barcelona, 1977. 
El tradicional foralismo carlista fue evolucionando con timidez. En 1957 Carlos Hugo, hijo de don Javier, ya hablaba de "espíritu foral renovado ${ }^{37}$. Con el tiempo, y bajo la influencia del sentimiento anticolonialista de los años 60 , algunos sectores del carlismo llegarían incluso a defender el derecho de autodeterminación. Pero el punto final asumido por el partido fue el federalismo. No obstante, en los años de la transición, el Partido Carlista formó parte de todas las plataformas que, en las diferentes nacionalidades del Estado, defendieron los estatutos de autonomía.

\section{CULTURA OBRERA Y SINDICALISMO}

La inquietud de los carlistas por las consecuencias del proceso industrial, y por ende, de los problemas religioso-morales y de lucha de clases que ello conllevaba, ya tuvo su plasmación en plena tercera guerra carlista, cuando la diputación carlista de Cataluña emitió en 1875 un decreto, paternal y conciliador, pero de inequívoca defensa de la clase obrera ${ }^{36}$.

Si la caridad y el mutualismo fomentado en los círculos carlistas habian cubierto una cierta función social entre sus miembros hasta los años diez, ahora, la explosiva coyuntura requería otras actitudes sobre la cuestión social. Máxime cuando la base social del carlismo habia aumentado su porcentaje de trabajadores urbanos. Es por estos años cuando don Jaime, de mentalidad moderna y progresista, no dudó en proclamarse socialista y manifestar su gran preocupación por los problemas sociales ${ }^{39}$. Fue en este contexto cuando el carlismo impulsó un sindicato llamado Corporación General de Trabajadores-Unión de Sindicatos Libres de España, nombre tomado de los belgas que inspiró el padre Gafo, un dominico que escandalizaba a las clases altas porque en sus conferencias afirmaba que a los obreros les pagaban sueldos miserables ${ }^{40}$. La fundación de este sindicato fue el 10 de diciembre de 1919 en Barcelona ${ }^{41}$, de acuerdo con el siguiente relato:

«Por la noche, un centenar de trabajadores acudieron a la calle de la Tapiceria, número 32, junto a la catedral, sede de uno de los veinte Ateneos Obreros Legitimistas, esto es, carlistas, que había en la ciudad. Este movimiento contaba con importantes núcleos entre las clases humildes que siempre se habian opuesto a los sindicatos por motivos políticos. Sin embargo, en junio del año anterior sus juventudes acordaron durante un congreso, además de otras muchas cosas, corregir la injusticia de la sociedad española y, desde entonces, numerosos obreros carlistas, como los allí reunidos, se habían afiliado a la CNT quizás con la esperanza de in-

37 Discurso en el Acto carlista de Montejurra de 1957 en: Don Carlos-Hugo Príncipe para el futuro, SUCCVM, Zaragoza, 1967, p. 14.

38 Toledano, Ferran Carlins i Catalanisme, Farell, Sant Vicenç de Castellet, 2002, pp. 159-160.

39 Clemente, Josep Carles, Historia General del Carlismo, cit., p. 356.

40 LEÓN-IGNACIO, Los años del pistolerismo. Ensayo para una guerra civil. (Las luchas obreras en la Barcelona de los años veinte. Un sangriento drama que explica la historia posterior de España), Planeta, Barcelona, 1981, p. 104.

${ }^{41}$ Colin M. Winston, lo sitúa en le mes de octubre. Ver: Winston, Colin M., La clase trabajadora y la derecha en España, 1900-1936, Madrid, Cátedra, 1989, p. 113. 
fluir en ella. (...) se celebraba aquel acto convocado por Ramón Sales, un joven militante del Sindicato Único Mercantil y, a la vez, del círculo carlista Crit de la Pàtria. Dicho joven pretendia fundar una nueva organización obrera vinculada a su movimiento, igual que la UGT al socialismo, proyecto que contaba con el apoyo de varias personalidades del partido, como Salvador Anglada o Pere Roma, que le acompañaban en aquel instante e incluso de don Jaime, el pretendiente al trono. Sales expuso su idea a los reunidos. La CNT ya no defendía los intereses de los trabajadores, sino de los grupos anarquistas que la dominaban. Por tanto, debía crearse una nueva sindical. Sus interlocutores (...) lo consideraban muy difícil y además, creian que podía dividir a la clase obrera. Uno consideró que, decididos a abandonar la CNT, ingresaran en los sindicatos católicos, lo que fue rechazado unánimemente. A los sindicatos católicos se les tenía por nidos de esquiroles ya que la Iglesia, en la que se inspiraban, estaba por completo integrada en le orden burgués" ${ }^{42}$.

Estos sindicatos, llamados «libres», renunciaron al confesionalismo y, en contraste con los católicos, eran sindicatos controlados y dirigidos por trabajadores, hicieron uso de negociaciones, pero también de huelgas y hasta de boicots, y no dudaron en recurrir a la violencia para poder sobrevivir en la Barcelona del "pistolerismo". Colin M. Winston ha desmitificado la estereotipada imagen de los libres como una banda de matones al servicio de los patronos, insistiendo en su función movilizadora y de lucha por ganarle espacio al anarcosindicalismo ${ }^{43}$. En el País Vasco y Navarra se fueron formando sindicatos libres ya entre 1910 y 1912, llegando a actuar conjuntamente con UGT, CNT y los Solidarios Vascos. Uno de sus fundadores, el carlista vizcaíno Pedro Olaortua, dejó escrito cómo se crearon y su fin: "la unidad de los trabajadores contra el sistema capitalista, en total autonomía"44:

Durante los años de la Republica, el ímpetu sindical y de protesta social de años anteriores había ido cambiando hacia otro más conservador, fruto sin duda de la integración al partido de grupos integristas y burgueses que, aunque contaban con poca base, poseían nutridas y poderosas cúpulas que coparon las primeras filas del partido carlista con los resucitados nombres de "Comunión" y "Tradicionalismo ${ }^{45}$. Estas nuevas elites del carlismo ahogaron aquel paréntesis de protesta social, para ir permutándolo por lo que Javier Ugarte llama el ethos, un género de discurso a base de valores y signos que fomentan una nostalgia del pasado hablando de la sociedad y de la urbe en términos unitarios y no de beligerancia de clase $^{46}$. La alternativa "sindical» de esos años fue la Obra Nacional Corporativa, con su sección agraria, cuya meta era la incorporación de patronos y obreros carlistas, donde se pondrían en práctica las ideas socialcatólicas ${ }^{47}$. Sea como

42 LEÓN-IGNACIO, Los años del pistolerismo, cit., pp. 103-104.

43 Winston, Colin M., La clase trabajadora y la derecha en España, 1900-1936, cit., pp. 110-167.

44 Clemente, Josep Carles, El Carlismo en el Novecientos español 1876-1936 Huerga y Fierro, Madrid, 1999, pp. 69-70.

45 CanAl, Jodi, El carlismo, cit., pp. 294-295.

46 Ugarte, Javier, La nueva Covadonga insurgente. Orígenes sociales y culturales de la sublevación de 1936 en Navarra y el Pais vasco, Biblioteca Nueva, Madrid, 1998, pp. 229-231.

47 BLINKHORN, Martin, Carlismo y contrarrevolución en España, 1931-1939, Crítica, Barcelona 1979, p. 380 . 
fuere, lo cierto es que las bases seguían siendo proletarias tal como lo observa el escritor de origen falangista José María Fontana:

«En Reus había también obreros "de derecha" (...) en primer lugar los militantes del carlismo; luego, algunos pocos católicos, y no faltaban los acomodaticios que buscaban ventajillas al arrimo de los "amos". Los primeros se guarecían en el "Centro Tradicionalista" (...) Para mí el carlismo - al que respetaba y admiraba literariamente después de haber leído a don Ramón del Valle Inclán- fue siempre un misterio, asimilable a los cátaros, superior a mis pobres entendederas, y cuyos planteamientos viscerales chocaban con mi lamentable racionalidad, si bien iba por allí algunas veces (...) el ambiente era netamente proletario y militante, a tal extremo que los ricos de Reus daban una discreta vuelta para no pasar ni por su acera (...) no se atrevían con ellos ni siquiera los marxistas (...) La afinidad proletaria hizo que los odios contra ellos fueran sañudos..." ${ }^{48}$.

Pero la cultura propiamente sindical no se recuperaría en el carlismo hasta 1963 - si exceptuamos el «sindicalismo estudiantil» de la AET, del que hablaré más adelante - con el nacimiento del MOT (Movimiento Obrero Tradicionalista). Fue fruto de una nueva generación que no había vivido la guerra civil. Antes de su aparición ya se publicaba en Murcia la revista Vanguardia Obrera, cuyo primer número lo definía como luchadores de un sano obrerismo que no cayera de rodillas ante el capitalismo liberal. EI MOT mantuvo una línea paralela a la AET, con la que le vinculaba la preocupación social y el deseo de reforma del carlismo. Aunque criticaban la concepción marxista de la lucha de clases, la comprendía como legítima defensa ante el ataque de la oligarquía; consideraban que la única diferencia con los movimientos marxistas se reducía al ámbito de lo religioso, un aspecto todavía importante en esta época. En un artículo dedicado por Vanguardia Obrera al fundador de la JOC (Juventud Obrera Católica) se señalaba, junto al catolicismo, también la importancia del marxismo como gran fuerza ideológica para el hombre de nuestro tiempo. Opuestos al sindicalismo vertical del régimen, aspiraban a la consecución de un sindicato que debía ser libre, único por rama de producción, democrático, horizontal y órgano de representación política. Planteaban además la superación del capitalismo, el control de la seguridad social y la redención obrera. Pero también se plantearon iniciativas para promoción de viviendas sociales, cooperativas de producción, de consumo y de crédito ${ }^{49}$. Algunos carlistas optaron, en la década de los sesenta, por su militancia paralela en la JOC o en la HOAC. Al final de esa experiencia algunos abandonaron el partido, pero otros dejaron esos colectivos de obreros católicos para continuar en el carlismo.

La última experiencia sindicalista del carlismo fue la Federación Obrera Socialista (FOS), que se fundó a principios de los años setenta y tuvo su origen en trabajadores militantes del Partido Carlista. Aunque fue financiada por el partido e ideológicamente coincidía en la alternativa socialista autogestionaria, no recibió en

48 Fontana, José Maria, Dos trenes se cruzan en Reus, Acervo, Barcelona, 1979, pp. 339-340.

49 Caspistegul, Francisco Javier, El naufragio de las ortodoxias, cit., pp. 108-112. 
ningún momento un apoyo explícito, ya que se mantuvo independiente del partido. Su mayor fuerza la tuvo en Navarra, con presencia en importantes fábricas de Pamplona. Tanto es así que Enrique Múgica conectó con sus dirigentes con la idea de que fuese pilar en el desarrollo de la UGT. Sin embargo, no se llegó a ningún acuerdo porque los delegados del FOS, que mantenían tesis asamblearias e ideas antipartido y anarquizantes, eran refractarios al PSOE ${ }^{50}$.

En relación a la presencia carlista en Comisiones Obreras, Marcelino Camacho recuerda en una entrevista su participación en la fundación de CCOO y las reuniones en el círculo carlista de la calle Limón de Madrid en la más absoluta clandestinidad ${ }^{51}$. Sin embargo, unos años más tarde, cuando desde el Frente Obrero del Partido Carlista ${ }^{52}$ se impulse la "corriente unitaria" - junto al MC y el PSPpara contrarrestar la influencia del PCE, se verá enfrentado al sector mayoritario de Camacho. En una encuesta realizada entre los miembros del Frente Obrero, el $85 \%$ se mostró favorable a vincularse a la USO por su mayor grado de independencia ${ }^{53}$.

\section{LA EXPERIENCIA JUVENIL Y ESTUDIANTIL}

En primer lugar, hay que decir que el colectivo de estudiantes carlistas fue siempre menor al de obreros, pero también fue proporcionalmente menor en relación a los estudiantes vinculados a otras tendencias políticas, ya fueran estas de derechas o de izquierdas. La razón es evidente, por un lado porque la mayoría de estudiantes provenían de clases privilegiadas, mínimas en el carlismo, y por otro porque los estudiantes de las clases privilegiadas que optaban por «traicionar» a su clase tomaban opciones de tipo liberal o de izquierdas, más propias de ambientes intelectuales. No obstante hubo una asociación carlista, la Asociación de Estudiantes —o Escolar- Tradicionalista (AET), vinculada al mundo colegial y universitario desde antes de la guerra civil que duró hasta finales de los años sesenta.

Desde sus inicios la AET sostuvo una buena parte de la actividad cultural del carlismo, aunque en los turbulentos y bélicos años treinta estuvo también influenciada por formas de acción directa callejera y proporcionó, además, oficiales y requetés durante la guerra. En aquellos años vivían los estudiantes en un ambiente

50 IRIARTE, José Vicente, Movimiento obrero en Navarra (1967-1977) Organización y conflictividad. Gobierno de Navarra, Pamplona, 1995, pp. 91-95.

51 TARRES, Joan, "Marcelino Camacho, la coherencia" en El Federal, $n .{ }^{\circ} 8$, enero, 2001, p. 8. En la comarca de La Plana Alta de Castelló, las CC.OO. fueron fundadas casi exclusivamente por carlistas (ver MiRAlLES, Josep, “Aproximació al carlisme de la ciutat de Castelló (1966-1977)» en IV Seminari sobre el carlisme (Solsona, 15-16 de marzo de 1996) Columna, Barcelona, 1997, p. 310.

52 En los años 70, tras la experiencia del FOS, y con el fin de estar presente en distintos ámbitos de la sociedad, el Partido Carlista desplegó la política de frentes de lucha como el Frente Obrero; además existían los frentes de estudiantes, barrios, profesional y campesino (ver: CANAL, Jordi, El carlismo, cit., p. 376).

${ }^{53}$ Caspistegul, Francisco Javier, El naufragio de las ortodoxias, cit., pp. 250-251. 
de exaltado romanticismo juvenil, mitificando los héroes carlistas de las pasadas guerras; se movian entre el lirismo y la tarascada, pero eran cultos e idealistas, incluso utópicos, con una cierta conciencia social; hacían representaciones teatrales, fomentaban el escultismo, el ejercicio físico, el compañerismo, la generosidad y la rebeldia. En Pamplona iniciaron en 1933 la reconstrucción del requeté haciendo maniobras militares y ejercicios de tiro, y enfrentados a la táctica parlamentariaconservadora de las cabezas de la Comunión Tradicionalista. Editaron la revista a.e.t. y participaron, junto a jóvenes obreros, en la iniciación de grupos folclóricos de danzas vascas que pasearon, durante la República, por toda España y las regiones vascofrancesas ${ }^{54}$.

Terminada la guerra civil, en la que sus miembros participaron como boinas rojas en los Tercios de Requetés, sublevados contra la República, la AET fue una de las organizaciones de la Comunión Tradicionalista que se mantuvo más activa. Ya en la propia guerra el carlismo comenzará a sufrir lar represalias de Franco, que continuarían después. Confinamientos y detenciones eran demasiado frecuentes para unas gentes que habían luchado en el bando vencedor. El estudiante Artur Juncosa relata en una publicación dos de sus detenciones, una de ellas por hablar catalán en Madrid ${ }^{55}$. Tras la negativa de los dirigentes carlistas a participar en la $\mathrm{Di}$ visión Azul, según Clemente los propios elementos de la AET se habían propuesto luchar al lado de los aliados contra los alemanes ${ }^{56}$.

En el año 1955 el carlismo sufrió una fuerte crisis originada por las indecisiones de don Javier de Borbón Parma a asumir la responsabilidad de la "realeza» carlista. En una importante reunión en Bilbao el secretario nacional de la AET dijo que si don Javier se decidía a dar paso a don Juan de Borbón, los carlistas se harían republicanos $^{57}$. Sin haberse cerrado la crisis, a principios de 1957 los estudiantes tomaban la iniciativa a favor de don Javier e intentaban dar respuesta a problemas sociales como inflación, salarios, capitalismo, monopolios, etc. Sin embargo, algunos carlistas eminentes no veían bien un ataque al capitalismo ${ }^{58}$. En noviembre de 1957 nació Azada y Asta, una revista universitaria, cultural y política fundada en Santander. El intento de su fundador y director, Francisco Javier Albornoz, consistía en una amplia superación de la cultura española desde su puesto de carlista. En sus páginas aparecían citados José Luis Hidalgo y Menéndez Pelayo; Balmes junto a Zenobia y Juan Ramón; Laín Entralgo y Pemán; Ortega y Pedro Caba junto al P. Ramírez. En sus editoriales se decian cosas como: «La política tradicionalista no se halla sujeta a ninguna cláusula religiosa, no es una religión doctrinal.» En el número 3 del boletín de la AET, los jóvenes carlistas expresaban en forma de poema su postura:

54 UGARTE, Javier, La nueva Covadonga insurgente, cit., pp. 277-279.

${ }_{55}$ JUNCOSA, Artur, "L'organització del moviment universitari carlí», cit., pp. 210-212.

${ }^{56}$ Clemente, Josep Carles, El Carlismo contra Franco, cit., p. 37.

57 Lavardin, Javier, Historia del último pretendiente a la corona de España. Ruedo Ibérico, París, 1976, p. 26.

58 Idem. p. 31. 


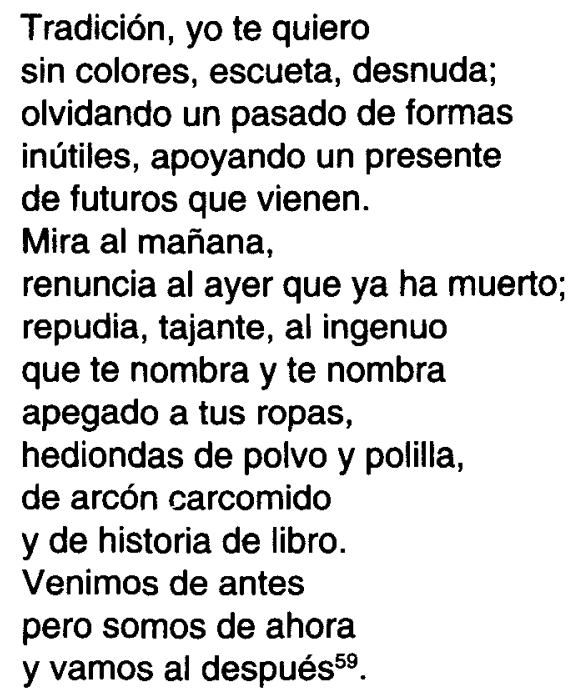

Fruto de las luchas estudiantiles de 1956 en Madrid se fue rompiendo en parte el sistema monopolístico del SEU. Se llegó a conseguir que fueran representativos los cargos de delegado de curso y de facultad. Los estudiantes carlistas procuraron obtener estos puestos, máxime cuando la dirección de la Comunión Tradicionalista asumió, con el escepticismo o la oposición de las bases, una táctica "colaboracionista" ${ }^{60}$. Es en este contexto también cuando, en 1961, nació en la clandestinidad la izquierdista FUDE, que se lanzó a copar los cargos sindicales al igual que los carlistas ${ }^{61}$. Durante la época en que el SEU fue dirigido por Manuel Regalado, un hombre de talante abierto, los estudiantes carlistas se ocuparon del área de cultura, en la que desarrollaron su labor desde una perspectiva progresista. Con ellos se organizó en Madrid el segundo ciclo de cine soviético y el primer homenaje a García Berlanga; en teatro se representaron las Comedias Bárbaras de Valle-Inclán, obras de Max Aub y de Tennessee Williams y recitales de García Lorca. En 1963 se salió al exterior y en Ginebra se logró, en un centro judío, programar una semana de cultura joven española con exposiciones de pintura, recitales, etc. Importantes artistas como el escultor Venancio Blanco o el grabador Marcoida se presentaron a concursos de artes plásticas que se convocaron también en Madrid 62 .

Empujado el carlismo por una generación de jóvenes nacidos en la posguerra y con una «secretaria» en sintonía con ellos, en torno a Carlos Hugo, hijo de don Javier, se inició a comienzos de 1965 una nueva etapa regeneradora que haría his-

${ }^{59}$ Idem. p. 65. En relación a Azada y Asta, ver también CLEMENTE, Josep Carles, Historia General del Carlismo, cit., p. 737.

60 Idem. pp. 48-50.

61 NicoLÁs, Encarna y ALTED, Alicia, Disidencias en el Franquismo (1939-1975) Diego Marín Librero Editor, Murcia, 1999, p. 75.

62 E.O. «Intervención en la Universidad» en El Federal n. ${ }^{\circ}$ 15, noviembre, 2002. p. 13. 
toria en el carlismo del siglo $\mathrm{xx}$. Algunos sectores dirigentes del carlismo de la guerra civil se escandalizaron, porque consideraban que el carlismo estaba en manos de no carlistas, de gente joven sin preparación adecuada. Pero el propio «rey» carlista ya hablaba no sólo de sus derechos, sino de los derechos del pueblo, porque había que llegar a la participación de todos y la democracia, más aún que en votar, consistía en participar. Los recurrentes enemigos del 18 de julio desaparecían del panorama carlista. Paralelamente, se volvía de nuevo al progresivo divorcio entre el carlismo y el régimen con todo lo que él significaba ${ }^{63}$. Fruto de esta situación nacía en Zaragoza la editorial SUCCVM (Sección Universitaria del Círculo Cultural Vázquez de Mella) que, dirigida por jóvenes intelectuales carlistas, muchos de la $\mathrm{AET}$, se dispuso a propagar esa visión del carlismo64.

En 1966, estudiantes carlistas de la AET de Cataluña también participaron en el congreso constituyente del Sindicato Democrático de Estudiantes de la Universidad de Barcelona, junto a representantes de otros colectivos estudiantiles de España y extranjeros, y con la presencia además de profesores, intelectuales y artistas, lo que provocó la represión del Gobierno ${ }^{65}$.

\section{LA «CULTURA»DE LA VIOLENCIA}

El turbulento siglo XIX estuvo marcado por un variado catálogo de violencia política, en el cual hay que mencionar también las llamadas guerras carlistas, que han merecido muchos estudios de diferente enfoque e interpretación. En cualquier caso, el carlismo -como el liberalismo- las mitificó y de alguna manera contribuyó a mantener durante el siglo xx un cierto culto a la violencia con aires de romanticismo.

Esa mitificación propició que el espíritu levantisco se plasmara, en octubre de 1900, con el levantamiento de partidas en Cataluña y el País Valenciano, que fracasaron. La cúpula del partido desautorizó las insurrecciones y depuró responsabilidades. Pensaban en aquel momento que las partidas no eran ya más que fórmulas arcaicas, y su fracaso fruto de una lectura errónea de la realidad de España y del propio carlismo, así como una inadecuación de las formas de violencia a esa realidad $^{66}$. En cualquier caso, ese espíritu guerrillero, más o menos romántico, se mantuvo latente y se plasmó en realidades de forma recurrente hasta mediados de los años 70 como tendremos ocasión de comprobar.

Mientras que los círculos respondían ya a fórmulas políticas urbanas, la transformación en el campo militar adaptado al combate callejero se iría plas-

63 LAvardín, Javier, El último pretendiente, cit., p. 250-256.

64 Entre 1966 y 1968 aparecieron una decena de títulos tales como: ¿Qué es el Cartismo?; Breve antología del Pensamiento Carlista Moderno; Valle-Inclán y el Carlismo; Esquema doctrinal carlista; Carlismo 67; Doctrina social del Carlismo; Carlismo rebelde; Don Carlos-Hugo Príncipe para el futuro.

65 NicolÁs y ALTED, Disidencias en el Franquismo (1939-1975), cit., p. 76.

66 CANAL, Jordi, "La violencia carlista tras el tiempo de las carlistadas: nuevas formas para un viejo movimiento" en Violencia política en la España del siglo XX, Julı̇́, Santos (dir.) Taurus, Madrid, 2000, p. 27. 
mando a partir de 1907 con la fundación del requeté, vinculado estrechamente a los elementos jóvenes del carlismo. Por aquellos años de enfrentamientos callejeros con grupos rivales se produjo en Barcelona la "Semana Trágica», en la que los carlistas salieron a la calle en defensa de círculos, iglesias y conventos amenazados de incendio o destrucción ${ }^{67}$. Unos años más tarde, cuando se fundaron los Sindicatos Libres, esa paramilitarización, unida a la retórica del combate, la sangre y los mártires, fueron semilla de los enfrentamientos con los cenetistas.

En los años treinta el requeté emergió, tras un tiempo de desactivación, como fuerza paramilitar, de la mano de la AET, en unos años en que el moderno espíritu autoritario impregnó a la sociedad y la violencia se impuso por doquier. Con el requeté el carlismo fue el primer grupo que poseyó en España una milicia en el sentido "moderno" de estas organizaciones. Los excesos que a ojos de la Comunión Tradicionalista cometía la República en general, y los revolucionarios en particular, favorecieron el engrandecimiento del requeté y la consolidación de una alternativa conspirativa que inicialmente se planteó como un levantamiento exclusivamente carlista, al estilo de los del siglo XIX. Pero finalmente, y contra esa tradición, se llegó a unos acuerdos con el general Mola en Navarra, que supuso la acción contra natura al lado del Ejército español. Por eso Gabriel Cardona dice que los carlistas eran la única fuerza colocada fuera de su órbita ${ }^{68}$. En cualquier caso fue tal la importancia de esa aportación civil al alzamiento castrense -la más importante en los primeros meses ${ }^{69}$ - que desdibujó la idea de estricto golpe militar. Pero muy pronto la mayoría de los carlistas se vieron decepcionados, lo que les hizo entrar en una dinámica de confrontación con Franco que reprimió todo intento de autonomía real del carlismo.

Capítulo aparte merece la cuestión de las represalias cometidas en las retaguardias de ambos bandos durante la guerra. Los carlistas, como elementos comprometidos con el alzamiento, fueron víctimas de la represión en el bando republicano ${ }^{70}$. Pero éstos, a su vez, también la ejercieron, fundamentalmente en Navarra, hasta tal punto que el jefe regional carlista se vio obligado a emitir una orden prohibiéndolas ${ }^{71}$. En los frentes de batalla, en cambio, parece que las cosas pudieron ser distintas a juzgar por lo que cuenta Ronald Fraser basándose en el recuerdo de requetés navarros:

67 Canal, Jordi, El carlismo, cit., pp. 265-266.

68 CaRdona, Gabriel, "Milicias y Ejércitos", La Guerra Civil, Historia 16, Madrid, 1986, vol. 10 , p. 52.

6950.000 voluntarios a mediados de agosto de 1936. Ver Borbón PARMA, María Teresa, CLEMENTE, Josep Carles y Cubero, Joaquín, Don Javier, una vida al servicio de la libertad, Plaza \& Janés, BarceIona, 1997. p. 113. Para ver la aportación humana del carlismo a la guerra, ver de Julio ARóSTEGUI, LOS combatientes carlistas en la guerra civil española 1936-1939, 2 vols. Aportes, Madrid, 1991.

70 Hay diversos estudios al respecto, como por ejemplo: SOLE, Josep Maria y VILLARROYA, Joan, La repressió a la reraguarda de Catalunya (1936-1939) 2 vos. Publicacions de l'Abadia de Montserrat, Barcelona, 1989. GABARDA, Vicent. La represión en la retaguardia republicana, 19936-1939 Alfons el Magnànim, Valencia, 1996.

71 Clemente, Josep Carles, El Carlismo en la España de Franco, cit., p. 209. 
«Los carlistas se habian levantado para defender la religión; no habría habido ningún levantamiento si los republicanos no hubiesen perseguido a la religión, pensó (...) Al ponerse en marcha la columna, las madres colgaban crucifijos del cuello de sus hijos. 'No te manches las manos de sangre si puedes evitarlo, no robes, sé bueno'..." ${ }^{72}$.

Terminada la guerra civil, y en un contexto de disidencia con el régimen franquista, el recurso a la violencia armada volvió a hacer acto de presencia por parte del carlismo cuando se produjeron los graves incidentes con la policía en Pamplona, en diciembre de 1945, con motivo de una manifestación dificultada por el gobierno civil para celebrar tanto la onomástica como la liberación de don Javier de un campo de concentración nazi ${ }^{73}$. Pero también contra el carlismo hubo violencia y provocaciones por parte de falangistas o policías como en los casos de Begoña en 1942, y los de Valencia o Sevilla en 1945. Mención aparte merecen lo crímenes en el acto de Montejurra en Estella (Navarra) de 1976 ante la pasividad de la fuerza pública alli presente, un acto que aún organiza cada año el Partido Carlista. Aquel año, los carlistas allí reunidos sufrieron la agresión por parte de una banda de terroristas internacionales que les causaron dos muertos y numerosos heridos. Según todos los indicios, este acto terrorista fue el primer crimen de estado, tras la muerte de Franco, al que luego seguirían los de los $\mathrm{GAL}^{74}$. Aquellos dos asesinados fueron marginados, como víctimas del terrorismo, por todas las instituciones, pero recientemente una sentencia de la Audiencia Nacional los ha reconocido como tales ${ }^{75}$.

El periódico recurso a la violencia armada por parte del carlismo, o de una parte del mismo, volvió a finales de los años sesenta cuando se crearon los Grupos de Acción Carlista (GAC). Este hecho fue propiciado por dos factores: por una parte, la influencia que tuvo en los sectores jóvenes del carlismo la figura del Che Gue$\operatorname{vara}^{76}$, sin olvidar la mitificación guerrillera del carlismo decimonónico y, en general, los movimientos de liberación frente al colonialismo de esa época; por otra, se incrementó su actividad cuando en 1968 el régimen expulsa de España a la familia Borbón Parma. Los GAC estaban formados por jóvenes militantes carlistas, pero el partido nunca reconoció oficialmente a esta organización, tal vez por eso en muchas zonas surgieron de forma espontánea y clandestina dentro de la propia Comunión Tradicionalista ${ }^{77}$. Comenzaron, en su primera fase, con acciones propa-

72 FRASER, Ronald, Recuérdalo tú y recuérdalo a otros. Historia oral de la Guerra Civil española. Crítica, Barcelona, 2001, p. 78.

73 Borbón Parma, Clemente y Cubero, Don Javier, cit., pp. 189-190.

74 CUBERO, Joaquín, «Montejurra 76. Un intento de interpretación» en Historia de la Transición y consolidación democrática en España (Madrid, 30 noviembre y 1 y 2 de diciembre de 1995), vol. 1 UNEDUAM, Madrid, 1995, pp. 29-48.

${ }^{75}$ Ver dossier en El Federal $n .^{\circ} 18$, diciembre, 2003.

76 Cuadernos de Historia del Carlismo, n. ${ }^{\circ} 31$, febrero 2004, p. 2 (Se trata de un Cuaderno dedicado a la AET, donde se reproduce un escrito de 1967 titulado: "El "Che" Guevara ha muerto").

7 Miralles, Josep, “El carlismo castellonense durante la transición democrática" en Historia de la transición y consolidación democrática en España (Madrid, 30 noviembre y 1 y 2 de diciembre de 1995), vol. 1 UNED-UAM, Madrid, 1995, p. 116. 
gandísticas radicales, pero pronto pasaron a la acción armada manteniendo algunas concomitancias con la ETA de aquellos años. Aunque les interesaba más la acción, su ideología evolucionó, a la par que la del partido, desde el progresismo socializante de los años sesenta hasta el socialismo de los setenta ${ }^{78}$.

\section{LAS FIESTAS RITOS Y CONMEMORACIONES CARLISTAS}

Una de las formas recurrentes, y no menos importante, de mantener vivo el movimiento carlista a lo largo de su historia, ha sido la realización de conmemoraciones de distinto tipo, ya fuesen religiosas o no. Asimismo, las concentraciones, los himnos, los romances, la iconografia, son todo factores que han contribuido al mismo fin, porque los pueblos entienden mejor este tipo de manifestaciones que las de tipo más académico y docto, y el pueblo carlista no fue una excepción, al menos en bastantes épocas de la primera mitad del siglo xx. Téngase en cuenta, además, que en el carlismo lo antropológico tiene un valor tanto o más relevante que lo político ${ }^{79}$.

Ya se ha dicho que de los círculos se saltó a la conquista del espacio público en los primeros años del siglo pasado. Lo mismo se conmemoraba una victoria que un alzamiento, un juramento real, o un recuerdo a "mártires" carlistas, que lo convertía en un lugar simbólico o en un motivo para la celebración periódica de un acto carlista o concentración de masas. Peregrinaciones o actos como Montalegre, Montejurra, Montserrat, Vila-real (Castellón) o Quintillo (Sevilla), etc., son ejemplos de ello ${ }^{80}$. Como lo son también símbolos como el árbol de Gernika, donde los reyes carlistas juraban los fueros, o El Pi de les Tres Branques, mitificado por Jacinto Verdaguer, donde en 1900 se alzó la partida del Noi de Vallcebre ${ }^{31}$. O el traslado, en 1913, de los restos del famoso general Tristany de Lourdes, donde murió olvidado y pobre, a Ardèvol, su pueblo natal ${ }^{82}$. También se realizaron banquetes conmemorativos, aunque más bien al nivel de elites, para celebrar alguna efeméride, alguna victoria electoral, o para homenajear a algún prohombre del carlismo como Valle-Inclán o Vázquez de Mella ${ }^{83}$.

78 Hay tres trabajos dedicados exclusivamente a los GAC: Desde la antropología, MACCLANCY, Jeremy "CAC: Militant Carlist Activism, 1968-1972", en: W.A. Douglas (ed.), Essays in Basque Social Anthopology (Reno, University of Nevada Press) 1989, p. 177-185. Desde su historia, OnfubiA, Javier, La resistencia carlista a la dictadura de Franco: Ios "Grupos de Acción Carlista" (G.A.C.) Magalia, Madrid, 2000. Desde la experiencia personal: Porro, lldefonso, Notas sobre los G.A.C. (Grupos de Acción Carlista) en: Cuadernos de Historia del Carlismo n. 11 , julio 1999. También en: ERIZ, Juan Félix, Yo he sido mediador de E.T.A. Mi larga andadura por un diálogo hacia la paz, Arnao, Madrid, 1986, (dos ediciones).

79 CASPISTEGUI, Francisco Javier, "El proceso de secularización de las fiestas carlistas" dentro del proyecto: Modernización económica y cambio social en Navarra 1939-1975. Un intento de comparación. (agradezco al autor el haberme proporcionado copia de este trabajo en 19 folios sin paginar).

Bo Ver reseña histórica de los orígenes, en 1910, de este aplec en: VIVES, José, Ahora Información, n. ${ }^{\circ} 59$, pp. $7-24$.

81 "Siempre lo hemos tenido claro", El Federal n. ${ }^{\circ} 14$, julio, 2002, p. 13.

82 Garrabou, Joan, Gent nostra. Tristany, Nou Art Thor, Barcelona, 1988, p. 50.

83 ZAMORA, Alonso, Vida y obra de Valle-Inclán, Círculo de Lectores, Barcelona, 1990, p. 82. ANDRES DE, Juan Ramón, El cisma mellista: historia de una ambición política. Actas, Madrid, 2000. Apéndices fotográficos. 
Capítulo a parte merece la celebración de los "Mártires de la Tradición", una fiesta que fue instituida por Carlos VII en 1895 y que se celebra el 10 de marzo, aniversario de la muerte del primer rey de la dinastía carlista. Una fiesta que, por su tradición, el franquismo intentó apropiarse en honor de todos los vencedores de 1936-1939, pero los carlistas no lo aceptaron y continuaron celebrando la suya al margen de FET y de las JONS ${ }^{84}$. En 1970 don Javier instituyó otra fiesta más prosaica pero necesaria para hacer partícipes a todos los carlistas en el sacrificio económico y el compromiso político: el "Día de la Lucha Carlista»" En todo caso también buscó un dia simbólico, el 2 de octubre, correspondiente al primer alzamiento carlista de Talavera de la Reina en 1833. Aunque la de los «Mártires de la Tradición» fue decayendo, el carlismo tradicionalista la hizo revivir y la sigue manteniendo y celebrando en la actualidad ${ }^{86}$.

Por lo que respecta a las canciones o himnos, eran muy frecuentes sus cánticos en todo tipo de celebraciones carlistas para amenizar los actos, y por supuesto en tiempos de guerra para dar moral a los voluntarios. La mayoría de las que se conservan pertenecen a tiempos de la Segunda República y la Guerra Civil, pero hay algunas cuyo origen es del siglo xIX, como el famoso Oriamendi. Sus contenidos suelen ser mezcla de componente religioso, patriótico o foral, legitimista y militar ${ }^{87}$. Otras más recientes, con letras de contenido social, se solían adaptar a conocidas canciones como es el caso de la Canción de los $G A C^{88}$. A partir de los años 70 , en el acto de Montejurra se oían canciones protesta de diversos cantautores del momento como Labordeta, Paco Ibáñez, Raimon, etc.

Inclusive hubo obras de teatro creadas con el fin de idealizar algün aspecto del carlismo, como Voces de Gesta de Valle-Inclán, una tragedia en verso que compuso en 1910 y cuyo contenido político legitimista le creó algunos problemas con el poder político ${ }^{89}$. Se trata de la escenificación idealizada del tema de la guerra carlista, mas desligada del tiempo y del espacio; una visión legendaria y romántica unida a fábulas épicas y caballerescas. En 1978 Francisco Javier Larrainzar publicó y estrenó, con gran éxito en Pamplona, Carlismo y música celestial, otra obra teatral donde se dramatiza la historia carlista desde el punto de vista de quienes realizaron la clarificación ideológica del carlismo ${ }^{90}$.

Otro elemento ritual y simbólico de un carlismo y una dinastía casi siempre en el destierro han sido precisamente las condecoraciones o cruces de Caballeros de la Orden de la Legitimidad Proscrita, que instituyó el pretendiente don Jaime en el

${ }^{84}$ CANAL, Jordi, El carlismo, cit., p. 345. También en: CASPISTEGUI, Francisco Javier, “Navarra y lo carlista. Símbolos y mitos" en Signos de Identidad Histórica para Navarra, II, Pamplona, Caja de Ahorros de Navarra, 1996, p. 363. (Agradezco a su autor el haberme facilitado copia de estas páginas).

${ }_{85}$ Clemente, Josep Carles, Historia General del Carlismo, cit., p. 583.

${ }^{86}$ Ahora Información n. ${ }^{\circ} 68$, marzo-abril, 2004, p. 39.

87 Una publicación editada por la Comunión Tradicionalista Cartista recoge medio centenar de himnos de este tipo: Canciones carlistas, Ecesa, Sevilla, 1981.

${ }_{88}$ Onrubia, Javier, La resistencia Carlista a la dictadura de Franco, cit., pp. 159-160.

89 ALBERCA Manuel y González, Cristóbal, Valle-Inclán, cit., pp. 147-149.

90 CASPISTEgul, Francisco Javier, "El proceso de secularización...”, cit., s/p. 
primer tercio del siglo $x x$, para concederlas a aquellos carlistas distinguidos por alguna causa. Uno de los más ilustres galardonados con la condecoración fue ValleInclán, que la recibió cuando ya adherido a la República seguía sintiéndose carlista; por esa razón la lució con orgullo en los actos republicanos ${ }^{91}$. Los descendientes del rey carlista continuaron con este ritual, de tal suerte que aún en el año 2000 y 2003 Carlos Hugo, el último representante de la dinastía proscrita, concedió en Trieste y Arbonne, respectivamente, condecoraciones a varios carlistas $^{92}$. Si bien es cierto que los beneficiarios suelen ser carlistas progresistas o socialistas, próximos al izquierdista Partido Carlista, ni éste ni la derechista Comunión Tradicionalista Carlista participan en el evento.

\section{EVOLUCIÓN CULTURAL E IDEOLÓGICA DEL CARLISMO}

Con lo expuesto hasta aqui creo que ha quedado someramente claro que el movimiento carlista ha sufrido una evolución evidente a lo largo del siglo xx, en especial en su segunda mitad. Pero la tónica general del carlismo, a decir del profesor Canal, ha sido - como todas - una misma cultura política, en continua reelaboración. Lo que pasa es que la excepcionalidad de su larga pervivencia to distingue de otros movimientos europeos, convirtiéndolo en un fenómeno peculiar. Considero que tanto sus orígenes como su final están más impregnados de inquietud social, frente a la mayor influencia religiosa de las etapas centrales. Aunque también ha habido ciclos. De tal suerte que en el siglo $x x$ también en sus orígenes la impronta social está más presente, hasta el advenimiento de la Segunda República, en que se troca en un discurso próximo al nacionalcatolicismo. Pero también es cierto que, de forma sincrónica, ha existido la disparidad de criterios en muchas materias. Por eso alguien ha hablado de este movimiento como «anarcocarlismo". He ahí la dificultad en enmarcar de una manera rotunda, no sólo la historia, sino la propia cultura política del carlismo.

En cualquier caso, el mayor cambio que se experimentó respecto a una supuesta ortodoxia de su doctrina fue en la segunda mitad del siglo XX, cuando inició el camino hacia una ideología socializante para terminar en la proclamación del socialismo autogestionario ${ }^{93}$. Y esta evolución ideológica se iba produciendo al mismo tiempo que ocurrían también unos cambios culturales que sin duda se daban en la propia sociedad.

Aunque me he centrado en la evolución del sector progresista del carlismo, no quiero olvidar la evolución que, aunque menor, también ha experimentado el sec-

91 ALBERCA y GonzÁLEZ, Valle-Inclán, cit., pp. 220-221.

92 ClEMENTE, Josep Carles, Carlos Hugo de Borbón Parma. Historia de una disidencia, Planeta, Barcelona, 2001, p. 265. Ver también Arbonne 2003, publicación sin fecha, de 8 pág, editada por el Círculo Cultural Vázquez de Mella de Bilbao, que reproduce las palabras de Carlos Hugo en dicho acto.

93 Una visión interna de la evolución en: BORBÓn PARMA, María Teresa, La clarificación ideológica del Partido Carlista. EASA, Madrid, 1979. 
tor tradicionalista que mantiene ser el auténtico representante de la ortodoxia. Una muestra de esa evolución, nada desdeñable, sería su clara opción por el pacifismo - en esto coincide con el Partido Carlista- en la línea, eso sí, de la doctrina oficial de la Iglesia en su interpretación más conservadora, al igual que en los aspectos culturales y de moral. Ese pacifismo de todos los carlismos, puesto de manifiesto en el rechazo a la invasión de Irak, ciertamente es un importante cambio si tenemos en cuenta que su historia es, en gran medida, la de sus conflictos armados, ya sean de raíz social, religiosa o política. Claro que también los movimientos revolucionarios son pacifistas hoy en España, tanto en su actuación política interna, como con relación al resto del mundo. La cultura de la paz ha calado en el carlismo y en los revolucionarios modernos. Solamente algunos sectores del neoliberalismo español parecen seguir apostando por la necesidad de la guerra, aunque sea camuflada de "ayuda humanitaria" para resolver los conflictos en el mundo moderno.

En otro orden de cosas, el carlismo se ha pensado en muchas ocasiones a sí mismo como una sola y gran familia, unidos todos por los vínculos de la sangre derramada en las guerras. Para el profesor Jordi Canal, la gran familia carlista se componía, como las tradicionales, de padre, madre e hijos, roles que encarnaban, en los años de la Segunda República, el pretendiente, don Alfonso Carlos I, su esposa María de las Nieves de Braganza, y todos los carlistas, empezando por los dirigentes, caracterizados como hijos mayores. Esta imagen permitía la presentación del carlismo como un todo armónico, distinguiéndolo del resto de partidos. Algunos veían con recelo su denominación como "partido", por eso restablecieron la palabra "comunión", más próximo al de "familia". Este autor hace referencia a narradores carlistas que hablan de "los relatos marciales escuchados en las noches de invierno por niños que se comían al narrador con los ojos, y cuyos corazoncitos rompian el pecho con la esperanza de que algún día serían grandes y harían hazañas como aquellas" (Francisco Martín Melgar); otros textos de Pérez de Olaguer y López Sanz en la década de 1930 y en la posguerra se llenaron de estas escenas de madres orgullosas por la muerte de sus vástagos bajo el lema carlista o dando las gracias a Dios por haberles proporcionado en la persona de sus hijos un mártir ${ }^{94}$. Es evidente, pues, la importancia de la familia como elemento de transmisión ${ }^{95}$.

Pero también en esto ha experimentado otro cambio importante. Aunque en algunos casos se sigue el mismo proceso de transmisión rutinaria de lo recibido, se complementa potenciando y desarrollando dichos rudimentos. El predominio sociológico del tradicionalismo-carlismo en Navarra durante el franquismo se mantuvo en buena medida a través de la familia, factor clave, aunque no único, para el proceso de socialización del carlismo. Las transformaciones de esa sociedad y el cambio de modelos produjeron un debilitamiento de la familia tradicional y por ello el

94 CANAL, Jordi, “La violencia carlista tras el tiempo de las carlistadas...", cit., pp. 46-48.

95 SÁnchez, Josep, El carlisme al territori de l'antiga didcesi de Tortosa, ob. cit. Vol. 1, p. 21. 
abandono de ese importante elemento en la configuración del carlismo tradicional ${ }^{96}$. Otro fenómeno se dio en torno a los años sesenta y principios de los setenta; fue cuando, en el proceso de evolución, se acercaron al carlismo gentes cuya tradición familiar era nula o muy débil, pero en estos casos, más importante que la tradición familiar, era el conocimiento de de la doctrina adquirida a través del estudio y la lectura. Así es como un entrevistado por el profesor Caspistegui pudo decir: "creo que era Pío Baroja que decia que el carlismo se cura leyendo, ipues yo llegué al carlismo leyendo! "97.

José María Castroviejo, aunque desde un carlismo de elite, ya plasmó con un punto de romanticismo, pero magistral y poéticamente, ese papel de la familia en la transmisión de la lealtad al carlismo. Pero al mismo tiempo deja entrever un cambio cultural en un texto de 1966 que, tal vez por ello, desmitifica la idea tan extendida de un carlismo santurrón propagada por el integrismo y el neotradicionalismo:

«Me vuelan al recuerdo (...) las emociones de mi niñez, cuando los ojos se abren, como pozos profundos, a la luz del milagro. Unas emociones prendidas en el culto y el fervor del carlismo galaico. Realmente el carlismo era una religión honda y encendida, sin demasiadas concesiones al beaterio. Había una estética carlista, pero había, sobre todo, una ética (...) dentro del decálogo no escrito del carlismo, podíamos escribir preceptos como (...) Amar al pueblo y desdeñar el dinero -mi abuelo solía decir que el dinero necesitaba por lo menos tres generaciones para hacerse perdonar-, sobre todo en su gruesa versión de la burguesía capitalista; estar siempre dispuestos a toda aventura, muerte o riesgo que la causa demandara, sin reaseguro (...) un "vivir peligrosamente" (...) practicar la caridad, sin bombo ni platillo (...) comprender y excusar todas las debilidades humanas - sobre el sexo, p.e., los carlistas fueron liberales, lo que tiene importancia en un país obsesivo en el que casi es considerado como el único pecado-, pero ser incompatibles con la villanía y el deshonor; afabilidad y relación cristiana intensa con el humilde y el enemigo noble (...) amor a las cosas que "naturalmente están ahi": la parroquia, el municipio, los oficios, "las Españas" que decía Gracián y que deben formar el conjunto "armónico" de la Península Ibérica; un estupendo sentido de la dignidad ante el poder (...) en la que la figura del rey era amada, pero nunca torpemente adulada (...) La verdad es que ya mi bisabuelo se había semiarruinado en el servicio de la causa (...) Mi abuelo anduvo, en su primera juventud, metido en conspiraciones y luchas (...) por lo que cayeron encima del ya menguado patrimonio familiar y de sus personas nuevas expropiaciones, cárceles duelos y otros quebrantos, lo que no lograron mellar la entereza de los leales. Don Ramón del Valle-Inclán (...) relata (...) una de estas entregas con emoción insuperable (...) Cuando venia a Galicia (...) pasaba siempre por casa de don Juan Vázquez de Mella. Aún lo estoy viendo con su barba rojiza, su chaleco blanco y su puro (...) Era, para mí, superior, hablando en intimidad que como orador famoso. Oratoria ésta que ha quedado en varios aspectos trasnochada (...) En casa se había recibido, por un motivo familiar, una afectuosa carta de don Jaime, y el gran tribuno, que venía de pa-

96 CASPISTEgUI, Francisco Javier y PIÉROLA, Gemma, "Entre la ideología y lo cotidiano: la familia en el carlismo y el tradicionalismo (1940-1975)" en Vasconia, 28, 1999, pp. 45-56 (agradezco a los autores el haberme proporcionado copia de estas páginas).

97 CASPISTEgul, Francisco Javier, “Navarra y lo carlista. Símbolos y mitos”, cit., p. 359. 
sar una temporada con el rey (...) no paraba de contar (...) Venían otras muchas gentes por casa -curas, profesores universitarios, estudiantes, hidalgos, obreros... - ya que el carlismo, sustancialmente popular, nunca fue un movimiento de cortesanos ni de banqueros..." ${ }^{98}$.

Por los días en que se escribía este texto, nuevas generaciones carlistas ya llevaban algunos años tratando de recuperar ese fondo socialista del que ya hablaron Unamuno o Aruro Campión ${ }^{99}$. Ya hemos visto cómo en 1957 los jóvenes estudiantes carlistas intentaban dar respuesta a los problemas del momento atacando «a la burguesía y al capitalismo, asi en abstracto, con fraseología marcadamente socialista" según expresión de "algunos carlistas eminentes" " ${ }^{100}$. Aunque la idea de socialismo, entendido como «la afirmación de la Sociedad frente al Estado», ya se había utilizado en el seno del carlismo en tiempos de Vázquez de Mella, cuando en 1909 dijo que el carlismo como fuerza social que es, en caso de quedarse sin rey, iria a engrosar el socialismo ${ }^{101}$. Aunque entendía que los socialistas habían desvirtuado y usurpado el concepto por la inflación que hacian del Estado ${ }^{102}$. Por eso, la futura idea de "socialismo de autogestión global»" ${ }^{103}$, basada en la participación de la sociedad en todas las esferas que le compete, no estaba tampoco tan alejada de esos planteamientos de principios del siglo xx. También el propio don Javier, fiel a su profunda religiosidad cristiana, afirmaba en mayo de 1974: "En nuestro afán superador perseguimos alcanzar la construcción de un estado socialista de autogestión que responde a un viejo y profundo anhelo cristiano del carlismo: devolver al pueblo su soberania» ${ }^{104}$. En realidad no era ninguna novedad que un rey carlista declarara su fe en el socialismo, pues cincuenta años antes ya lo habia manifestado su antecesor don Jaime.

Sin embargo, el camino hacia la plasmación concreta de los ideales socialistas en el seno del carlismo no fue fácil, estuvo acompañado de profundos debates e importantes crisis. Pero en contra de lo que pudiera parecer, no todos los problemas fueron creados por el sector conservador que, a medida que se veía imposibilitado de enderezar el rumbo que se había tomado, iba paulatinamente abando-

98 CAstroviejo, José María, “El carlismo gallego en mi recuerdo", cit.

99 Citado por Josep Carles Clemente en Los carlistas, Istmo, Madrid, 1990, p. 37. Campión, Arturo, Blancos y negros (guerra en la paz) Beñat Idaztiak. San Sebastián, 1934, p. 337. Se trata de la reedición de esta novela cuya primera edición data de 1899. El texto dice: «...la taberna de Aquilino Zazpe, centro popular muy activo de los carlistas. Aquilino, como todos los jornaleros de la tierra baja, donde el carlismo es opinión radicalmente democrática, con puntos y ribetes socialistas, era acérrimo partidario de don Carlos y, con él a una, los miembros de su familia".

100 Lavardin, Javier, El último pretendiente, cit., p. 31.

101 Clemente, Josep Carles, Historia General del Carlismo, cit., p. 355.

102 Zabala, Pedro José, “Mella rebelde» en: Carlismo rebelde, SUCCVM, Zaragoza, 1968, p. 3.

103 BORBÓN PARMA, Carlos Hugo, La vía carlista al socialismo autogestionario. El proyecto carlista de socialismo democrático, Grijalbo, Barcelona, 1977. En este libro, el autor desarrolla la filosofía del «socialismo de autogestión global» que el Partido Carlista había hecho suyo oficialmente en II Congreso del Pueblo Carlista celebrado en Arbonne en junio de 1972. Un texto más reciente y actualizado pensado para la actual sociedad globalizada, en El Federal, n. ${ }^{\circ} 19$, abril, 2004, dossier titulado: «Nuestro socialismo".

104 OnRuBIA, Javier, El pensamiento cristiano de don Javier de Borbón Parma, Fundación Amigos de la Historia del Carlismo, 1997, p. 14. 
nando la militancia y en algún caso excepcional, expulsados del partido. También desde la izquierda, algunos sectores ansiosos de quemar etapas entorpecían el proceso evolutivo carlista. En cualquier caso, cuando el núcleo dirigente se propuso democratizar las elites de la Comunión Tradicionalista hacia 1964-65, mediante cursillos de formación y confrontación de esquemas ${ }^{105}$, sabían que esa autorrevolución interna significaría romper con el tradicional esquema oligárquico, y que por tanto habria que asumir las consecuencias de la participación democrática de los militantes en todas las áreas. Así fue como se abrió lo que podía ser la caja de Pandora, que de hecho condujo a las crisis apuntadas.

Pero se logró algo nuevo en el carlismo: la participación de las bases de una manera formal, regulada, y a todos los niveles. Fue tal la libertad de opinión que se llegó incluso a plantear críticas al sistema monárquico, que se seguía ofreciendo como alternativa a la sociedad, aunque se tratase de una Monarquía socialista ${ }^{106}$. En este sentido, las FARC, un importante grupo de presión de militantes jóvenes muy influido por el marxismo, nacido en 1971 al calor del proceso de clarificación ideológica, debatió sobre la Monarquía siendo «...derrotada por abrumadora mayoria la idea de que la Monarquía era esencial al Carlismo» ${ }^{107}$. El caso es que, finalmente, Carlos Hugo, independientemente de sus derechos legales a la realeza, acabó siendo el presidente electo del Partido Carlista.

En temas relacionados con la concepción tradicional de la familia, la mujer y el sexo, las viejas ideas asumidas de hecho por amplios sectores de la militancia de edad más avanzada, también acabaron haciéndose añicos, en correspondencia con los cambios que en este terreno también iba asumiendo el resto de la sociedad civil. Así, por ejemplo, Laura Pastor, una nueva dirigente del Partit Carlista del País Valencià, elegida por las bases del partido, se declaraba en 1976 partidaria de la planificación familiar; del aborto, aunque no como solución definitiva; de las relaciones extramatrimoniales; y de la no marginación de los homosexuales. Por lo que respecta al papel de la familia tradicional, la consideraba como una reproducción a escala reducida de la estructura social burguesa que calificaba de autoritaria, discriminadora de la mujer, materialista y egoísta ${ }^{108}$. Más extraordinarias y novedosas eran las actitudes cuando provenían de otro tipo de militantes, especialmente cuando se trataba de personas de edad avanzada, que se manifestaban en un sentido parecido, más aún si se trataba de mujeres, como es el caso de Lali Hu-

105 Clemente, Josep Carles, El carlismo contra Franco, cit., p. 249.

106 Las críticas no fueron sólo desde la izquierda carlista; un sector derechista desgajado de la Comunión Tradicionalista hacia ya algunos años, divulgó un texto en verso que decia así: "iMonarquia Socialista! / iLo que faltaba por ver! / Por esa tortuosa pista / lleva a su Pueblo excarlista / el nefasto Don Javier". Ver MIRALleS, Josep, Los heterodoxos de la causa, Huerga y Fierro, Madrid, 2001, p. 122. Aunque se trate de una novela, está basado en un escrito real (esta novela, además, encierra en sí misma la evolución política y cultural del carlismo del siglo xx a través de una familia carlista valenciana).

107 OnRubia, Javier, Notas para una historia de las Fuerzas Activas Revolucionarias Carlistas (F.A.R.C.) 1971-1973, Magalia, Madrid, 2003, p. 30. Sobre las FARC, ver también: A propósito de las F.A.R.C: entrevista a Paco Ubierna, Madrid, Cuadernos de Historia del Carlismo, n. 33, julio, 2004.

108 MiRalles, Josep, «Laura Pastor: semblanza d'una dirigent carlista del País Valencià durant la transició democrática" en El carlisme i la dona, V Seminari d'Historia del carlisme (Solsona, 13 y 14 de marzo de 1998), Fundació Francesc Ribalta, Solsona, 1999, pp. 40-41. 
mada, madre del que fuera Secretario Federal del Frente Obrero del Partido Carlista, José Ramón Rincón, que había sido bastante activa en el partido. En una entrevista realizada en 1997, cuando contaba 81 años de edad, siendo ya viuda, manifestaba al autor que combinaba el baile de los fines de semana con la misa y comunión dominical; le parecía una bobada que alguien le dijera que ser de izquierdas fuese incompatible con las prácticas católicas. Ella se consideraba muy creyente y rezaba todos los días por sus hijos (dos de los cuales -gemelos y con los míticos nombres de Carlos y Javier - padecen una grave enfermedad, la esclerosis múltiple), pero afrontaba con realismo, sin histerismos ni traumas los divorcios o convivencias «sin pasar por la vicaría» de sus hijos ${ }^{109}$.

En líneas generales puede decirse, sin embargo, que las madres de familias tradicionales carlistas que habian evolucionado seguían manteniéndose en un plano subsidiario, pero en algunos casos muy necesario, sobre todo cuando la familia estaba en peligro permanente, con detenciones y encarcelamientos de sus miembros, como es el caso de Calixta Pérez. Cuyo esposo, Tomás Martorell, y la mayor parte de sus trece hijos mantenian un fuerte compromiso no sólo con el Partido Carlista, sino con otros colectivos afines como los GAC o la FOS ${ }^{110}$. También desde las altas esferas del carlismo se ponía de manifiesto ese cambio cultural de signo feminista, como puede verse en el libro que escribió la entonces esposa del príncipe Carlos Hugo, Irene de Holanda ${ }^{111}$. Abundando en el tema que se está tratando aquí quizá convenga hacer mención también del protagonismo que tuvieron algunos militantes carlistas de Barcelona en el desarrollo del movimiento de liberación gay de Cataluña en los años setenta ${ }^{112}$.

109 Miralles, Josep, «La dona carlista durant el franquisme i la transició: tres casos significatius de La Plana” en VI Congrés d'Històtia i Filologia de La Plana (Nules, 4-5 abril, 1998) Ajuntament de Nules, 2001. p. 361

110 Martorell, Tomás, Andanzas de un carlista del siglo $X X$, Fundación Amigos de la Historia del Carlismo-Biblioteca Popular Carlista, Pamplona, 2001, pp. 85-102.

111 Borbón Parma, Irene, La mujer y la sociedad, Plaza y Janés, Barcelona, 1979.

112 Miralles, Josep, Los heterodoxos de la causa, cit., p. 136-137. El Marc Zurano de la novela está inspirado en Manolo Zabala Sevilla, fallecido en enero de 1998, que fue activo militante del movimiento gay y del carlismo, asi como dirigente de CCOO en Barcelona. Otro conocido carlista, víctima del terrorismo de extrema derecha, y activista gay, es Ferran Lucas, de quien Joan Samit escribe en el Periódico de la Semana (suplemento de El Periódico de Cataluña) del 17 al 23 de marzo de 1997, en su p. 13, en los siguientes términos: "Los diputados que votaron en contra, por lo visto prefieren que un niño muera de hambre en el Zaire antes de que lo adopten los maricones". Femando Lucas Zaragoza es contundente en su crítica a los grupos parlamentarios que rechazaron el proyecto de ley de parejas de hecho. Lucas es miembro del comité ejecutivo del Partit Carli de Catalunya. Su cara ensangrentada y sus ojos vidriosos con visión de muerte dieron la vuelta al mundo hace 21 años, tras la concentración carlista de Montejurra de 1976, en la que elementos ultras mataron a dos partidarios de Carlos Hugo e hirieron a otros cinco, uno de ellos Fernando Lucas, de extrema gravedad. Aunque no ondea su homosexualidad como bandera, no la oculta. Curiosamente, en el carlismo tradicionalista de la CTC, también he detectado el intento de "reivindicar", aunque desde el anonimato de su foro en internet, y desde la soledad, el respeto que se merecen los homosexuales, explicado por un "Joven asistente a los campamentos Cruz de Borgoña", donde dice: "No estoy de acuerdo con la simplificación y homofobia que ha despertado en este foro un comentario de Javier del libro Los heterodoxos de la Causa. En primer lugar quiero decir que yo también he estado en los campamentos 'Cruz de Borgoña' donde aprendí muchas cosas y valores importantes, pero mis inclinaciones homosexuales me las tuve que guardar muy adentro. En ese sentido el libro en cuestión supuso un gran descubrimiento para mí, ya que me ayudó a aceptarme a mí mismo en mi condición de homosexual" (Mar, 13, 2003). 